\title{
External Migration Problems of Kyrgyzstan Population in the Post-Soviet Period
}

\author{
Ainagul Dzhooshbekova1, Gulnaz Chynykeeva ${ }^{2}$, Ainagul Abduvapova ${ }^{3}$, Kursanbek Turdubaev ${ }^{4}$, \\ Ulukbek Elchibekov5, Sabyrkul Arstanov6, Chynykhan Satybaldieva6, Samara Osmonova6, \\ Ertabyldy Sulaimanov 7 , Asya Abduvapova ${ }^{8}$, Baktygul Osmonova², Zhypargul Abdullaeva9* (])
}

\author{
${ }^{1}$ Departmemnt of Kyrgyzstan History and Ethnology, I. Arabaev Kyrgyz State University, Bishkek, Kyrgyzstan \\ ${ }^{2}$ Department of General History and Teaching Methods, Osh State University, Osh, Kyrgyzstan \\ ${ }^{3}$ Department of Social Work, Osh State University, Osh, Kyrgyzstan \\ ${ }^{4}$ Department of Pediatrics, Medical Faculty, Osh State University, Osh, Kyrgyzstan \\ ${ }^{5}$ Department of Social Technologies and Humanitarian Sciences, Osh Technological University, Osh, Kyrgyzstan \\ ${ }^{6}$ Department of Kyrgyzstan History, Archeology and Ethnology, Osh State University, Osh, Kyrgyzstan \\ ${ }^{7}$ Department of History, Zhalal-Abad State University, Zhalal-Abad, Kyrgyzstan \\ ${ }^{8}$ Department of Government and World Languages, Osh Technological University, Osh, Kyrgyzstan \\ ${ }^{9}$ Science and Research Department, Osh State University, Osh, Kyrgyzstan \\ Email: *jypar.science@oshsu.kg
}

How to cite this paper: Dzhooshbekova, A., Chynykeeva, G., Abduvapova, A., Turdubaev, K., Elchibekov, U., Arstanov, S., Satybaldieva, C., Osmonova, S., Sulaimanov, E., Abduvapova, A., Osmonova, B., \& Abdullaeva, Z. (2021). External Migration Problems of Kyrgyzstan Population in the PostSoviet Period. Advances in Applied Sociology, 11, 113-129.

https://doi.org/10.4236/aasoci.2021.113009

Received: February 5, 2021

Accepted: March 13, 2021

Published: March 16, 2021

Copyright $\odot 2021$ by author(s) and Scientific Research Publishing Inc. This work is licensed under the Creative Commons Attribution International License (CC BY 4.0).

http://creativecommons.org/licenses/by/4.0/

\begin{abstract}
The rapid and large-scale migratory movements of people in the post-Soviet period caused by the collapse of the USSR and the formation of new sovereign states, which have a whole range of consequences in all spheres of the socio-political and socio-economic life of peoples. The destruction of the once mighty state and the single economic division of labor and associated with the incredible scale of unemployment, massive impoverishment of the population, and a sharp social and property stratification of society led to a socio-economic crisis. As in all former Soviet republics, the socio-economic situation in Kyrgyzstan has deteriorated, which is the main reason for the increase in the migration mobility of its ethnic groups, including the Kyrgyz. The purpose of the study is the identification of external migration process features in south Kyrgyzstan. The following research methods used in this work: a survey of respondents, analysis of survey materials, surveillance, and field survey of households in the southern region, conversation with local government officials, members of migrant families, analysis of statistical materials, and analysis of mass media materials.
\end{abstract}

\section{Keywords}

External Migration, Population, Post-Soviet Period, Migration Dynamics, 
Labor Migration, Factors Affecting Population Migration

\section{Introduction}

Kyrgyzstan has long been an agricultural region. The process of economic liberalization from 1991 to 1994, firstly, affected the agriculture of the republic. The transition to new forms of ownership was accompanied by massive destruction of collective farm system that contributed to the emergence of several depressed areas and led to the release of a significant mass of the population. First of all, the widespread downsizing of collective and government farms led to the decline of the well-functioning agricultural system. Even in a market economy, the bulk of marketable products produced by large enterprises, many farmers go bankrupt in the competition. Therefore, it is difficult for small farms to survive in market conditions. The youth fell under the blow of unemployment, being the least socially protected category of the population. The reform of the agrarian sector, as an industry where the bulk of the population (70\%) of the country is concentrated and giving it sources of residence, was based on the privatization of collective and state farms, land reform, and the creation of a class of farmers. The privatization program for processing enterprises began from 1992 to 1993 and was completed by the end of 1999 . There were 49,277 peasant farms in the republic. Legal conditions have been created for the functioning of farms. As a matter of priority, the following laws have been developed: "Land Code", "On State Registration of Rights to Real Estate", "On Mortgage", "On Cooperation", "On Peasant Economy" (Tazabekov \& Saginbaeva, 2003).

The transition to market relations led to the emergence of a new social category of unemployed. For the period from 1991 to 1998, the dynamics of unemployment growth were uneven. The period from 1996 to 1998 was characterized by a generally stable improvement in the main economic indicators of development and an increase in the income of the population. According to the results of 1998 , the volume of GDP increased by $2.1 \%$. Its growth is largely facilitated by an increase in production in industry and agriculture. After the decline of GDP from 1991 to 1994, there has been determined significant growth in the health sector. Due to the course on market reforms and support for medium and small businesses from 1994 to 1998, the share of small businesses in the total GDP grew steadily and reached the level of $30 \%$. It should be noted the increase in the share of manufactured products in farms, which in 1998 reached $11 \%$ in the total gross output (National Statistical Committee of the Kyrgyz Republic, 1999).

In most of the high-mountain regions of the republic, the population of small towns and villages found themselves in the zone of mass concentration of poverty. As a result, it was concluded that poverty in Kyrgyzstan covered all the main socio-demographic groups of the population (National Program for Overcoming Poverty "Araket", 1999). Therefore, overcoming poverty, especially in 
rural areas, where it is most widespread, has been identified as the main direction of the activities of state bodies, which remains relevant up to the present time.

According to our ethnic sociological research conducted in 2009, a contingent is constantly formed among the Kyrgyz of Kyrgyzstan, which can be attributed to potential migrants, meaning a group of residents whose unmet needs were realized "in the form of certain interests, desires" (Perevedentsev, 1975).

In this work, we identified regional differences in the causes of migration and its factors. Population migration is affecting the location, structural distribution, reproductive movement of the population, production means, labor resources, and mainly determines the characteristics of social economic relations (Akylbekov \& Makiev, 2019). The most obvious regional difference between the northern and southern regions is the relative and absolute numbers of external labor migrants. The number of labor migrants from the southern regions is 5 times higher than the number of immigrants from the northern regions. This difference is because $65 \%$ of the population of Kyrgyzstan is represented by the rural population, dependent on agricultural production. Statistical data show that in the Osh, Zhalal-Abad, and Batken regions, in general, based on the objective availability of arable land, there is 3 times less land per villager than in the Chui and Naryn regions. This is the main factor of regional differences in the reasons and sizes of migration flows.

To determine the main factors of Kyrgyz population migration in the south, respondents were asked the question: "Do you want to leave for another place?" Percentage of positive answers was $35 \%$, negative answers were $50.5 \%$, and $14.5 \%$ of the respondents were found difficult to answer. In the settlements where ethnic sociological research was carried out, there were mainly those who could not leave their place of residence and move to other places for several reasons, in particular, due to old age, family circumstances, diseases, boys and girls who did not receive passports, as well as individuals working in rural management, teachers, doctors, i.e. "People are self-sufficient." Most of the working-age population has already moved to other regions and outside the country, so half of the respondents answered negatively. In the villages, mainly school-age children and the older generation, looking after children, home and household, remained. Nevertheless, a little more than a third of the respondents would like to move and more than $10 \%$ found it difficult to answer, if they are included in the number of those intending to leave their place of residence, it turns out that almost every second respondent wants to migrate to other places.

\section{Factors Affecting Population Migration}

Migration is determined as a complex system, which has complicated microstructure and evolutionary characteristics (Gou et al., 2020). The reasons for migration were manifested most often in the form of several motives, which are differentiated depending on gender, age, marital status, education, and work ac- 
tivity. Socio-economic factors that determine the standard of living of the population are the main ones in terms of impact on migration sentiments in Kyrgyzstan. Factors affecting migration processes in the Kyrgyz Republic during the years of independence, patterns and features in the development of migration processes in Kyrgyzstan at the present stage, as well as regulation of migration processes in the Central Asian Economic Community, have been described previously (Omarov, 2000; Kumskov, 2002; Kumskovte al., 1998). Our analysis is confirmed by materials from other studies. Interesting results in this regard were provided by a sociological study of the problem on internal migration of the population of the Kyrgyz Republic, commissioned by the IOM from May to September 1998 by the research association "Inforex ltd" in all regions of the country with an assessment of the level of internal and external labor migration for the period starting from 1992 to 1998 (Evening Bishkek newspaper, 1998). Analysis of the long-term development of migration processes showed that the external migration reorientation directions in Kyrgyzstan began already in the 1970s, and in the early 90s, there was only an intensification of a long-established trend. The growth of population migration outflow, first, was limited in time and restrained by political measures after 1994. Second, the increase in the migration outflow did not occur due to a noticeable reduction in the inflow of immigrants. The country's attractiveness to immigrants or returning from abroad has greatly diminished. Third, the strong decline in international migration reflects the nation-building process in the former Soviet republics. Migration exchange of population with neighboring countries has decreased, but it has increased with several countries outside the CIS. Finally, fourthly, the nature of international migration must be considered taking into account the internal structure of the country and its geographic location. Understanding this impact, different countries should develop appropriate solutions to address the wide range of health issues affecting undocumented immigrants (Martinez et al., 2015).

\section{External Labor Migration}

Displacement of the population by external migration is becoming a significant problem (Williams \& Efendic, 2019). External labor migration of the Kyrgyz aimed mainly at two states: Russia and Kazakhstan. Therefore, our material was analyzed according to these two main directions of Kyrgyz migration. For Kyrgyzstan, solving the problems of mitigating the existing imbalance in economic development, expanding the spheres of employment by establishing integration ties with other CIS countries and, firstly, with neighboring countries of the Central Asian region, is of great practical importance. The Central Asian states that have embarked on the path of transformational transformations are fully experiencing the costs of their economic and political sovereignty.

Therefore, the solution of problems in the field of employment and regulation of the movement of labor directly depends on the state and prospects of development and mutually beneficial cooperation based on an agreement on the crea- 
tion of a single economic space. Cooperation at the regional level was initiated by the initiatives of three Central Asian countries: Kyrgyzstan, Kazakhstan, and Uzbekistan.

In 1994, in Alma-Ata, the Memorandum of Cooperation in the Field of Migration was signed. By decision of the government heads of three republics, an Interstate Council was formed, consisting of Presidents and Prime Ministers, other bodies, including a permanent body the Executive Committee of the Interstate Council. According to the decisions of the Council, the Program of Cooperation in the Field of Population Migration between the Kyrgyz Republic, the Republic of Kazakhstan, and the Republic of Uzbekistan (1997) was developed, signed, and ratified.

The Treaty on the Creation of a Common Economic Space between Kyrgyzstan, Kazakhstan, and Uzbekistan was signed in Cholpon-Ata in 1994 and was intended to play an important role among the agreements adopted both at the regional level and at the level of the CIS as a whole in the integration of the Central Asian republics. One of the most significant measures in the field of regulating labor migration processes was the adoption of the Law "On External Migration", which defines the powers, tasks, and procedures for interaction between government bodies to protect the legitimate interests of migrant workers. An important point is the introduction of compulsory registration with the migration service of all contracts concluded between Kyrgyz citizens and foreign employers of labor. This procedure should become mandatory for firms engaged in intermediary employment services, which will allow monitoring both the compliance of the terms of contracts with existing legislation and their subsequent observance.

\section{Protecting Migrants Rights}

To fulfill the agreement on the settlement of the resettlement process and the protection of the rights of migrants between Russia and Kyrgyzstan, as well as to improve the procedure for applying for the status of a migrant, the Legislative Assembly of the Jogorku Kenesh ratified the Treaty on the status of citizens of the Russian Federation permanently residing in the territory of the Kyrgyz Republic and, accordingly, citizens Kyrgyzstan living in Russia. This document defines the legal status of immigrants, which is as close as possible to the legal status of citizens of the country of residence. Immediate implementation of the Decree of the President of the Kyrgyz Republic adopted in 2000 "On additional measures to regulate migration processes" was the establishment of direct integration ties between the largest industrial enterprises of Kyrgyzstan and several regions of Russia, in particular, Sverdlovsk, Moscow, Omsk, and others one initiative of the Russian Government.

In December 2009, it generally approved the amendments to the Law "On the Legal Status of Foreign Citizens in Russia", as well as amendments to the Tax 
and Budget Codes. Firstly, we are talking about the introduction into practice of patents for work on the territory of the country, which will provide the right to legal work for hire from individuals, i.e. from the employer as a gardener, security guard, governess, etc., and for an unlimited time.

The dynamics of migration differ at different stages of migration processes. As a result of migration exchange with other countries for the period from 1991 to 2000, the republic lost over 700 thousand people (Alibi Newspaper, 2008). As Table 1 shows, the peak of external migration falls in 1993, when more than 120 thousand people left the republic. Since 2000, the activity of external migrants has increased again. After the March 2005 revolution, external migration intensified and its high balance dates back to 2007. The migration behavior of the population was affected by the global economic crisis followed by the April and June events of 2010.

The state has been implementing repatriation programs since 2001 when in August, the Decree of the President of the Kyrgyz Republic "On measures to assist ethnic Kyrgyz returning to their historical homeland" issued, and in 2002 the

Table 1. Dynamics of external migration of the population of the Kyrgyz Republic (National Statistical Committee of the Kyrgyz Republic, 2010).

\begin{tabular}{|c|c|c|c|}
\hline \multirow{2}{*}{ Years } & \multicolumn{3}{|c|}{ Total external migration } \\
\hline & Arrived & Departed & Migration growth, outflow (-) \\
\hline 1991 & 37.6 & 71.3 & -33.8 \\
\hline 1992 & 26.3 & 103.7 & -77.5 \\
\hline 1993 & 23.0 & 143.6 & -120.6 \\
\hline 1994 & 20.1 & 71.2 & -51.1 \\
\hline 1995 & 18.4 & 37.3 & -18.9 \\
\hline 1996 & 15.9 & 27.6 & -11.7 \\
\hline 1997 & 12.8 & 19.5 & -6.7 \\
\hline 1998 & 10.2 & 15.7 & -5.5 \\
\hline 1999 & 7.9 & 17.8 & -9.9 \\
\hline 2000 & 5.3 & 27.9 & -22.5 \\
\hline 2001 & 5.0 & 31.6 & -26.6 \\
\hline 2002 & 4.9 & 32.7 & -27.8 \\
\hline 2003 & 4.4 & 21.2 & -16.7 \\
\hline 2004 & 3.2 & 22.6 & -19.3 \\
\hline 2005 & 3.7 & 30.7 & -26.9 \\
\hline 2006 & 3.4 & 34.4 & -31.0 \\
\hline 2007 & 3.9 & 54.6 & -50.6 \\
\hline 2008 & 3.4 & 41.2 & -37.7 \\
\hline 2009 & 3.8 & 33.3 & -29.5 \\
\hline
\end{tabular}


Government of the republic adopted a package of measures to provide support and assistance to ethnic Kyrgyz. In 2006, the government approved the state program "Kairylman" (Government decree, 2006). The goal of the program was to facilitate the return and integration of ethnic Kyrgyz arriving in their historical homeland, primarily from Tajikistan and Afghanistan.

The specific geopolitical task of the program was to increase the share of the Kyrgyz concerning other ethnic groups, primarily the Uzbek, in the Fergana Valley. The authorities pursued a policy of restricting the entry to permanent residence of Uzbeks and Tajiks in the south of the republic. The action of the Kyrgyz government concerning the Uzbek demographic pressure is understandable: the size and current growth (400 thousand per year) of the population of neighboring Uzbekistan is too significant, and the southern regions, experiencing demographic pressure from the neighbor, are too remote, and thus torn off, as in terms of transport and economically, from the northern and metropolitan regions.

External migration in Kyrgyzstan is mainly at two governments: Russia and Kazakhstan. Therefore, our material was analyzed according to these directions of Kyrgyz people's migration. To solve the problems existing in the economic sphere of Kyrgyzstan, as well as to expand the areas of employment, it is necessary to establish integration ties with other CIS countries, including with neighboring countries in Central Asia. The transforming governments in Central Asia are experiencing the costs of the economic and political process of sovereignty. As a result, problems in the field of employment and control of the labor movement, depending on their decision prospects for development and cooperation on mutually beneficial terms.

One of the most important conditions for the stable existence of civil society is the creation of a well-thought-out regulatory framework for legal regulation of migration and resettlement of migrants. A similar base that taking into account international documents in the Kyrgyz Republic is recently forming with slow temps.

A scheme of normative legal acts is necessary to regulate public relations in the field of migration processes has been developed, and these acts are developed with the participation of state, local authorities and administration, as well as public organizations. In connection with the increasing scale and increasing role of labor migration in Kyrgyzstan, it is necessary to strengthen the role of the government in protecting the interests of labor migrants abroad, and to improve migration control concerning foreign citizens. Our government needs a strong and well-thought-out migration policy. We must fight corruption among employees of the migration service and law enforcement agencies. The task of the government of the Kyrgyz Republic is to create organizational and legal conditions that create an opportunity for the population to move for work to other countries, to be able to get jobs, and most importantly, to be socially protected with the least material and moral costs. 


\section{Migration Policy}

Scientists have studied the migration policy of Kyrgyzstan using data from the Global Galupp survey for 2008 (Gradirovsky \& Esipova, 2009). In their opinion, the Kyrgyz state ideologically encourages the monoethnization of the country, considering this process a condition for strengthening its state sovereignty, and considers migration policy as a means of achieving this goal. The government of the republic is unable to cope with the objectively formed powerful meridional migration drift, the meaning of which is that the population of the southern regions of Kyrgyzstan (Osh, Zhalal-Abad, Batken regions) is moving to the northern (Chui, Issyk-Kul valleys and Bishkek); Uzbeks and Tajiks from neighboring republics are striving to replace the displaced southerners, while the population of the country's northern territories is gradually shifting towards Kazakhstan, Russia, and the West. This population drift is part of the western migratory drift of Greater Eurasia. The migration policy of the Kyrgyz government is characterized as a policy of declared confrontation but in fact, an adaptation to strong human currents. Interstate treaties and agreements regulate external labor migration flow between countries, for example, labor migration between the Kyrgyz Republic and the Russian Federation is regulating by bilateral interstate relations (Elebaeva, 2013).

Over the nine months of 2010, more than 30 thousand people left the republic (Sydykov, 2010). The Russian Federation accounts for about $60 \%$ of the total number of migrants (Elebaeva, 2010). Kazakhstan accounts for about $40 \%$ of labor migrants from Kyrgyzstan. Only according to the official data of our fellow citizens there are 65 thousand people, and according to unofficial data about 100 thousand. According to the profile of their work, they can be divided into three main categories: seasonal agricultural workers, hired workers, and private entrepreneurs. The latter work in the field of trade in the markets of large cities and constitute the overwhelming majority. The issue of legalization of labor migrants is still open.

The main problems of migrants were registered at the place of residence and difficulties in obtaining permits for work. Now in Kazakhstan, there is a licensing system for foreign labor. The government of Kazakhstan sets annual quotas for its admission. In 2002, the Agreement "On Labor Activity and Social Protection of Labor Migrants" was adopted between the Government of the Kyrgyz Republic and the Government of the Republic of Kazakhstan, following which a quota was established for 7500 Kyrgyz migrants to work on tobacco plantations. In 2006, at a meeting of the prime ministers of both countries, a new quota was established for 10 thousand labor migrants from Kyrgyzstan.

According to these agreements, private companies organized in the capital Bishkek and in the southern cities located in Osh, Zhalal-Abad, and Batken, which were engaged in the employment of agricultural workers from Kyrgyzstan. Kyrgyzstan, which lasted until the end of the year. It was predicted that in this way 100 thousand illegal immigrants will get rid of the prefix "not". According to 
preliminary estimates, more than 150 thousand people were legalized.

About 24 thousand migration cards were handed over to the Kyrgyz people (Turganbaev, 2007). Despite this, the illegal entry of labor migrants significantly exceeds the number of legally employed. This has a very negative impact on their rights in the host country. Most labor migrants from Kyrgyzstan work without an employment agreement. Thus, they become completely dependent on the employer, who personally sets their wages and working conditions, often discriminates against their rights, and worsens living and working conditions. In 2010, Kazakhstan proposes to reduce the duration of citizens' stay in Kyrgyzstan without registration from 3 to one month, as new control of migration flows is being introduced. In particular, in Almaty, it was planned to do this by regulating the rules of registration and strengthening the responsibility of the owners of apartments and houses (Meshkova, 2005). The Ombudsman of Kyrgyzstan from November 10 to December 10, 2010, announced a month for human rights. One of the events of the month, by order of the Ombudsman of the Kyrgyz Republic, was the monitoring of the protection of labor migrants rights in the Almaty city and regions, where more than 13 thousand of our compatriots residing.

If earlier this period was 90 days, then after the April events it was reduced to 5 days. Until October 1 to 5 , in 2010, the migration police expelled 158 citizens of our republic, who could not get a residence permit under the laws of Kazakhstan. There are problems in the education of migrants children. By order of the Ministry of Education of Kazakhstan on December 27, 2007 (No. 659), foreign citizens children were expelled from schools. For example, 145 children were excluded from Astana schools (International crisis group, 2021). This event did not comply with the United Nations Convention on the Rights of Children and caused discontent among Kyrgyz migrants.

Only in September 2010, after the public intervention, the order was canceled, but as it turned out during the monitoring, in many places this issue has not yet been positively resolved. Therefore, a significant number of Kyrgyzstanis suffered a lot of inconvenience due to these problems. The migrants opened a private school where they taught their children for 100 USA dollars per month. These schools cannot replace full-fledged schooling. The migrants turned to the President of Kazakhstan and Kyrgyzstan, the Ministry of Labor, and the Migration of Kyrgyzstan. During a meeting with Minister A. Ryskulova, migrants asked for assistance in increasing the term of migration cards, at least by 30 days, and introducing a patent system for commercial activities of migrants. The Kazakh authorities are considering proposals regarding migrants employed in agriculture, who came from Nookat, Karasuu, and Uzgen districts of Osh oblast. The main problems of these migrants are low wages, poor working conditions, and lack of identity documents.

The Embassy of the Kyrgyz Republic in Astana and the Consulate General in Almaty provide local assistance to citizens of our country. Our diplomatic missions work in close contact with representatives of the Kyrgyz diaspora in the 
Republic of Kazakhstan. All the official structures involved in this process understand perfectly well: there is a need for both countries to develop a simplified mechanism for recruiting labor resources from Kyrgyzstan. Ultimately, both, we and Kazakhstan, which needs our labor migrants, benefit from this. Russia and Kazakhstan provide jobs for millions of Central Asian migrants, and this defuses tensions and protests that may arise from ineffective government policies. From 2004 to 2008, when there was progress in labor migration, 800 thousand Kyrgyzs, 1.5 million Tajiks, and 2.5 million Uzbeks left their homes and went to work in Russia and Kazakhstan. They worked on construction sites (40\% of workers are migrants), in retail trade, agriculture, and housing and communal services, and received less income for their work comparing to the paid residents. When the global economic crisis of 2008 hit, many of them lost their jobs, about 1 million people returned to their homes at the end of 2009 , but others stayed behind, went into an illegal position, and grabbed any job just to be able to send money home. According to experts, the return of migrants to their homeland and a general decrease in the number of remittances can cause social and political upheaval in the region (Esenaliev, 2004).

\section{Kyrgyz Labor Migrants in Kazakhstan}

Kyrgyz labor migrants in Russia and Kazakhstan are mainly working in the construction site, agriculture, and other industries where manual labor is used. About $16 \%$ of labor migrants are people who left for work 7 - 8 years ago and already have their own business, who also attract their relatives and compatriots to work (Sydykov, 2010). A large number of migrants are coming to Kazakhstan from neighboring Central Asian countries, mainly Kyrgyzstan, Uzbekistan, and Tajikistan (Ismayilova et al., 2014).

After 1991, with the introduction of a simplified procedure for obtaining Russian citizenship, it was issued by 250 thousand Kyrgyz (Sansyzbaeva, 2008). In 2006-2008, citizenship was received by 144 thousand citizens of Kyrgyzstan (Newspaper MSN, 2005). Citizens of all three countries of the world, according to interstate agreements, have a simplified procedure for obtaining the Russian citizenship to Belarus, Kazakhstan, and Kyrgyzstan. By the number of citizens who took advantage of these opportunities, Kyrgyzstan ranks first; in Kazakhstan, 447 citizens of Kyrgyzstan received citizenship in 2004; 9 months after in 2005, 480 people received citizenship, and this figure will increase. In 2010, after the April and June events, Kazakhstan strengthened control of customs, reduced quotas for employment, and problems arose with the education of children of Kyrgyz migrants. But, at the level of the two governments, this issue has been resolved positively. According to the consulting firms that work with foreign representatives, Kyrgyz migrants in Kazakhstan are representing in the field of computer technology. Our migrants also work in construction organizations of such largest Kazakh companies as Basic A and Elitstroy.

A lot of people work in Astana, and the majority employed in Almaty city. 
Unlike other labor migrants from Tajikistan and Uzbekistan, our staff is more highly qualified. Kazakhstani employers, as a rule, hire Kyrgyz citizens (International Crisis Group, 2021). The strong talent pool not only in business but also in politics has been diminished recently. The saddest thing is that migrants not only try to find work in Russia and Kazakhstan but also try to change their citizenship, i.e. they do not associate their future with their own country.

\section{Kyrgyz Labor Migrants in Russia}

The Ministry of Labor and Migration, together with customs officers, keeps records of migrants. Representative offices have been opened in 7 large cities of the Russian Federation. Starting from the Ural Mountains to Altai, Tuva, Yakutia, the Far East, 40 groups were organized that help migrants obtain permission, place of residence, work, wages, and support in legal disputes; people work voluntarily (Newspaper Zhany kylym, 2006).

The results of the analysis obtained from materials showed, that the largest flow of external labor migrants directed to Russia. A fifth of the respondents would like to go to Russia, almost half of the respondents intend to work temporarily and return home. $4 \%$ of respondents reported that they already work in Russia, $8 \%$ are firmly intending to permanently live and work in Russia, of which $32 \%$ are persons with higher, $17 \%$ prefer incomplete higher, and $14 \%$ prefer secondary education.

A well-thought-out social and migration policy of the Russian Federation, improvement of working conditions, provision of loans, and other measures attract migrants from Kyrgyzstan even more. An important factor in the outflow of Kyrgyz migrants to Russia was the fact that the Russian Federation with its neighboring governments in terms of the level of social wealth, reflected in GDP per capita. According to information sources, employment in Russia is more rewarding in connection with the global economic crisis; occasionally, many conditions for migrants' staying in Russia have become tougher. Many migrants were expelled, but they want to return back by any means (Taichabarov, 2006).

Kyrgyz graduates of the Moscow universities, who linked with their acquaintances in Russia, organized a public organization "Kyrgyz Birimdigi". The organization consists of several sectors and dealing with various migrant issues. Its main goal is to unite Kyrgyz migrants and students of Moscow universities, to organize meetings and concerts of Kyrgyz art masters, solve the problems of sending those who perished to their home country (Kyrgyz Tuusu newspaper, 2005). Currently, the Zamandash Association and the Zamandash Contemporary Party are actively working with migrants; in addition to coordinating, they directly address the problems of migrants outside of Kyrgyzstan.

In August 2012, the First Congress of Kyrgyzstan and Compatriots, initiated by these organizations, was held in Bishkek. The Congress adopted specific recommendations to improve the situation of migrants abroad and the socio-economic situation in Kyrgyzstan and sent them to Kyrgyzstan. In the course of our re- 
search, the respondents were asked the question "Do you want to change citizenship?" $33 \%$ of respondents expressed a desire to obtain dual citizenship of Kyrgyzstan and Russia. Among people with secondary specialized education, 37.5\% want to receive double citizenship (Mitrokhin, 2003). This is because they can easily find work in Russia. Many Kyrgyzs who wish to obtain Russian citizenship want to return to their homeland in the future.

At present, the labor market determines more the demand for specialists with secondary specialized education. In this regard, in our country, more attention is paid to professional lyceums and institutions that provide secondary specialized education. Many migrants admit that obtaining Russian citizenship is easier than renewing a work permit every time. According to one Moscow activist, the number of fictitious marriages with Russian women is on the rise. Many observers believe that the Kyrgyz who have received Russian citizenship will not move to Russia forever. They need Russian citizenship to facilitate employment. Many do not want to leave Kyrgyzstan at all, where they have children and elderly parents. However, in the future, migrants who have acquired double citizenship may face the need to make decisive choices. Children of migrants will find themselves more integrated into Russian society, and will begin to drag their parents to Russia. Moreover, Russian pensions, although insufficient for a normal life, are still higher than symbolic payments in Kyrgyzstan.

Nevertheless, even optimistic officials in Central Asian capitals believe that it will be two or three years before the Russian economy starts using foreign power at pre-crisis levels (Saparbek, 2007). In 2010, Russia provided 1000 jobs for tailors and construction workers. The Ministry of Labor and Migration of the Kyrgyz Republic is recruiting groups by professional parameters. Many of them are young, therefore parental consent is required, for families the consent of the spouses. The ministry bears great responsibility for the recruited groups and controls the conditions of their living and leisure (Borisenko, 2008).

The increase in the outflow of the indigenous population is facilitated by the relative exhaustion of the emigration potential, which consists of the already realized processes of the departure of its representatives from among the most mobile age and ethnic groups. A new tendency of the outflow of the most prepared part of the youth of Kyrgyz nationality is growing. According to official statistics, in 2001 only in the Sverdlovsk region of the Russian Federation, there were more than 300 thousand citizens of Kyrgyzstan, mainly of Kyrgyz nationality, employed in the sphere of "shuttle" trade and services.

Generally, the number of Kyrgyz people, who are permanently living and working in Russia (primarily in the Urals and Siberia) ranges from 400 to 700 thousand people (Kumskov, 2002). The sex and age composition of the population leaving the republic represented by the most economically and reproductively active human potential. So, in 2007, in the republic as a whole, the share of emigrants who are of working age accounted for $66 \%$. Among them, the number of women in working age who left the country was $51 \%$, a number of men was 
$49 \%$. The weight proportion of people up to the working-age and older than the working-age was $17.6 \%$ and $16.6 \%$, respectively (Kumskov, 2002). Over the past several years, an increase in the proportion of people with higher and secondary specialized education has been noted in the distribution of emigrants by the level of education. The presence of the observed processes of an increase in the outflow of qualified personnel from the republic testifies to the development of tendencies that are unfavorable for society as a whole, which may result in an acute shortage of professional labor.

Professions, positions, and types of economic activity distributed the emigrants who left the country due to the external migration outflow of the population in 2010. In the structure of the professional and official composition of the retired workers accounted for $24.5 \%$, specialists and other employees were $18.4 \%$, managers were 1.75 , others who did not indicate their official position was $54.4 \%$.

The economic activity of emigrants at the time of departure was as follows: among specialists and other employees, workers in the fields of education (23\%), as well as health and social services (12\%) prevailed; among workers-those employed in agriculture, hunting and forestry (22\%), in construction (15\%), in transport and communications (7\%) (Saparbek, 2007). External labor migration is now relieving social tension in the republic (National Statistical Committee of the Kyrgyz Republic, 2010). In Kyrgyzstan, only 5 firms have official licenses for the employment of migrants abroad (Nazaralieva, 2005). From big cities, Moscow, St. Petersburg, and Yekaterinburg (traditional centers of attraction for migrants), many move to the Far East. The share of workers leaving for Vladivostok and Khabarovsk, the main Far Eastern cities, increased in 2009 from 3\% to $5 \%$.

\section{Migration Conditions}

Even conditions are worse than in the European part of Russia, migrants still go and drag their relatives with them, creating communities in this region. They make $\$ 200$ - $\$ 300$ in a month and start to work their jobs. In any case, this is much more income than they could receive at home (Newspaper white sail, 2008). None of the Central Asian labor supplying countries are effectively pursuing the desire to create jobs at home. Besides, Russia's need for migrants will be stronger than Bishkek's desire to keep its citizens for a long time to come. According to Rosstat, the natural decline in the Russian population from 2008 to 2025 will be 11 million people; the number of able bodied Russians will decline even faster by 1 million per year in the period from 2011 to 2017. This will seriously affect human resources in general and the economy. Russia will have to continue its policy of attracting a large number of foreign workers or its new citizens. The experience of other countries has shown that labor migration has both positive and negative consequences for human security. Everyone knows the calculations made by economists, who say that the export of labor is 5 times 
more efficient than their production activities. In some Arab countries, labor export earnings account for $20 \%-30 \%$ of the national budget. Labor migration makes it possible for sending countries to save funds for training and retraining specialists, improving their qualifications. Many exporting states, such as Egypt, Turkey, Pakistan, have entered the group of medium developed countries due to the export of labor resources.

Kyrgyzstan is one of the donors of labor resources to other governments. The Russian Federation accounts for about $60 \%$ of the total number of migrants. In Russia, Kyrgyz migrants mainly work in construction, agriculture, trade, i.e. where unskilled manual labor is used. Kazakhstan accounts for about $40 \%$ of labor migrants from Kyrgyzstan.

By profile, the work can be divided into three main categories: seasonal agricultural workers, wage earners, and private entrepreneurs. The latter work in the field of trade in the markets of large cities and constitute the overwhelming majority. Labor migration of the population is a real way to avoid a social explosion due to the impoverishment of the population. Without efforts to create an efficient economy, eradicate corruption and improve the quality of social services, the state will remain dependent on its more developed neighbors. Unemployed migrants will add to the list of unresolved problems in the region, which includes the collapse of the Soviet infrastructure and disintegration, leading to blackouts and gas blackouts in the winter. Also, events in Afghanistan could spur the growth of domestic Islamic radicalism, which is a cause for concern. In the absence of reforms, the impoverishment of Kyrgyz society will continue, since all more or less educated, qualified, healthy people leave for Russia, Kazakhstan, and in the case of Russia, they accept Russian citizenship. Considering that quite a lot of educated and qualified specialists left the country after the collapse of the USSR, Kyrgyzstan cannot afford to lose people further if it wants to survive as a viable and independent government.

\section{Other Conditions}

One of the most important conditions for the stable existence of civil society is the creation of a well-thought-out regulatory framework for the legal regulation of migration and the settlement of migrants. A scheme of normative legal acts necessary to regulate public relations in the field of migration processes has been developed, and these acts are developed with the participation of government, local authorities, and administrations, as well as public organizations.

In connection with the increasing scale and increasing role of labor migration in the Kyrgyzstan, it is necessary to strengthen the role of the government in protecting the interests of labor migrants abroad and to improve migration control concerning foreign citizens. Taking into account international documents, the Kyrgyz Republic develops and adopts laws regulating migration processes. Migration of people caused by an objective condition, the desire of people to find better living conditions. 
The task of the government in the Kyrgyz Republic is to create organizational and legal conditions that create an opportunity for the population to move both within the country and to other governments, to get work there, social protection with the lowest material and moral costs.

According to a survey conducted in 2007 by the World Bank, official remittances sent to Kyrgyzstan amounted to $\$ 1$ billion 400 million, which is, on average, is equal to every Kyrgyz citizen who sends $\$ 1400$. The volume of official remittances from labor migrants in 2009 slightly decreased due to the financial crisis and job cuts in countries where migrants worked, amounting to $\$ 1$ billion (Newspaper Kyrgyz Tuusu, 2005). Note that these amounts exceed the budget of the Kyrgyz Republic. Besides, labor migrants, during their activities, improve their level of professionalism and acquire new specialties. At the same time, labor migration has several negative consequences for Kyrgyzstan in terms of human security. Firstly, the result of labor migration is a reduction in the number of labor resources. The villages are emptying; the shortage of personnel is growing both in the agricultural and industrial sectors. Due to the "brain drain" and the departure of qualified specialists, Kyrgyzstan annually lacks a significant number of its citizens of working age, who are potentially in demand in various sectors of the domestic economy. Migration also turns into many social problems: families destroyed, children grow up without parental care, there is a problem of migrant children, parents and the older generation remain abandoned. Mass labor migration from the Kyrgyz Republic negatively manifested itself in the deformation of the family structure, in particular, the gender and age composition, demographic, territorial, and socio-professional structure of the population because of the departure and reduction of the number of representatives of the younger generation. All this together leads to the degradation of family and marriage relations. Many men and women, having gone to work, often start another family in a foreign country and gradually reduce, and even stop sending financial assistance to their families at home. In the absence of reforms, the humanization of the Kyrgyz society will continue, since all more or less educated, qualified, healthy people leave for Russia, Kazakhstan, and in Russia, they are accepting Russian citizenship.

\section{Conclusion}

Considering that quite a lot of educated and qualified people left the country after the collapse of the USSR, Kyrgyzstan cannot afford to lose people further because wants to survive as a viable and independent government. Thus, analysis of the data indicates that due to the limited spheres of employment forms, and types of professional employment of citizens in the republic, the problems of stabilizing the flows of external migration of the Kyrgyzstan population are continuing to persist. In the presence of these reasons, the regularity of interdependence was clearly manifested, the level of economic development in the country and implementation of migration processes intensity. Modern external migration from 
Kyrgyzstan leads to large scale socio-economic and political consequences. For our country, the negative side of the Kyrgyz people departure abroad expressed in the fact, that most competitive and enterprising part of the population leaves the republic, thereby national economy is weakening, and the number of working people is decreasing. Mass migration of young people is negatively affecting demographic situation in the Kyrgyzstan and intra family relations.

Summarizing the above materials, we came to the following conclusions: Labor migration to Russia, Kazakhstan, and non-CIS countries has a positive significance for the development of Kyrgyzstan in today's transition period, as it stimulates the flow of income and the exchange of economic relations, helps to cushion inflation, and reduce the level of poverty.

\section{Conflicts of Interest}

The authors declare no conflicts of interest regarding the publication of this paper.

\section{References}

Akylbekov, T. A., \& Makiev, A. T. (2019). Migration Processes in the Social Development of Kyrgyzstan. Bulletin of the Moscow University of Finance and Law, 1, 117-125.

Alibi Newspaper (2008). Our Nation's Recent Condition and Future (p. 6).

Borisenko, L. (2008). Iron Discipline Is Needed to Raise the Economy (p. 3). Newspaper MSN.

Elebaeva, A. (2010). Migration Processes and the Rights of Labor Migrants. Yearbook on Human Rights in the Kyrgyz Republic for 2009 (pp. 43-57). Bishkek: The Kyrgyz Republic National Institute of Strategic Research.

Elebaeva, A. (2013). Migration Policy of the Kyrgyz Republic in Modern Conditions. Central Asia and the Caucasus, 16, 66-82.

Esenaliev, D. (2004). The Effect of External Labor Migration for the Economy of Kyrgyzstan Is Positive (pp. 8, 9). Bishkek: AKI Press.

Evening Bishkek Newspaper (1998). Is It Just One Step from Grant to Prison (p. 7)?

Gou, W., Huang, S., Chen, Q., Chen, J., \& Li, X. (2020). Structure and Dynamic of Global Population Migration Network. Complexity, 2020, Article ID: 4359023. https://doi.org/10.1155/2020/4359023

Government Decree (2006). On Approval of the State Program "Kairylman" to Assist Ethnic Kyrgyz Returning to Their Historical Homeland for 2006-2008” (No. 737).

Gradirovsky, S., \& Esipova, N. (2009). Migration Policy of the Kyrgyz Government: Opposition or Adaptation to Strong Human Currents (p. 33)? National Report, Bishkek: Ilim.

International Crisis Group (2021). Common People, Radicals, and Governments Are Interested in Labor Migration. https://www.fergana.ru

Ismayilova, L., Lee, H. N., Shaw, S., El-Bassel, N., Gilbert, L., Terlikbayeva, A., \& Rozental, Y. (2014). Mental Health and Migration: Depression, Alcohol Abuse, and Access to Health Care among Migrants in Central Asia. Journal of Immigrant and Minority Health, 16, 1138-1148. https://doi.org/10.1007/s10903-013-9942-1

Kumskov, G. V. (2002). Regularities and Features of the Development of Migration 
Processes in Kyrgyzstan at the Present Stage (222 p.). Bishkek: Ilim.

Kumskov, G. V., Kumskova, N. K., \& Suvankulov, A. R. (1998). Regulation of Migration Processes in the Central Asian Economic Community (89 p.). Bishkek: Ilim.

Martinez, O., Wu, E., Sandfort, T., Dodge, B., Carballo-Dieguez, A., Pinto, R., Rhodes, S. D., Moya, E., \& Chavez-Baray, S. (2015). Evaluating the Impact of Immigration Policies on Health Status among Undocumented Immigrants: A Systematic Review. Journal of Immigrant and Minority Health, 17, 947-970.

https://doi.org/10.1007/s10903-013-9968-4

Meshkova, E. (2005). Problems in the Regions. MSN. 2.

Mitrokhin, N. (2003). Labor Migration from Central Asian States. Otechestvennye Zapiski, 3. http://www.strana-oz.ru

National Program for Overcoming Poverty “Araket” 1998-2005 (1999). Bishkek: Kyrgyzstan Ministry of Justice.

National Statistical Committee of the Kyrgyz Republic (1999). Social and Economic Development of the Kyrgyz Republic 1994-1998: Annual Publication (pp. 9-35). Bishkek.

National Statistical Committee of the Kyrgyz Republic (2010). Population and Housing Census of the Kyrgyz Republic 2009 Book II. Part 3. (In Tables). Migration of the Population of Kyrgyzstan (p. 24). Bishkek.

Nazaralieva, N. (2005). Moskvada otkon zhyly 94 kyrgyzstandyk kaza bolup, anyn 70i kyinap olturulgon (p. 5). Newspaper Kyrgyz tuusu.

Newspaper Kyrgyz Tuusu (2005). Russia Kyrgyzstandin ekonomikasen investmentloo kyzykdar (p. 10).

Newspaper MSN (2005). Our People in Kazakhstan (p. 7).

Newspaper White Sail (2008). Household Mankurtism (p. 7).

Newspaper Zhany Kylym (2006). Youth. Unemployment. Future (p. 7).

Omarov, N. M. (2000). Migration Processes in the Kyrgyz Republic during the Years of Independence: The Results of the Decade (192 p.). Bishkek: Bilim.

Perevedentsev, V. N. (1975). From Village to City. Journalist, 10, 135.

Sansyzbaeva, A. (2008). Bizdin kyrgyzdar buyruk berip kalyshkan.

Saparbek, k. A. (2007). Emnege kurulushchularybyz Rossiyaga, Tushtuk Koreaga ketuudo (p. 7)? Newspaper Agym.

Sydykov, B. (2010). All Relates to Us. Forum. September 11.

Taichabarov, M. (2006). Iygiliktuu ish sapar. Kyrgyz Tuusu Newspaper, March 28, 3.

Tazabekov, M., \& Saginbaeva, A. (2003). Weak and Ineffective Agricultural Sector as a Mirror of the Kyrgyz Economy. Central Asia and the South Caucasus. Urgent Problems, 4, 342-343.

Turganbaev, T. (2007). Remittances of Migrants. Arguments and Facts Newspaper, 50, 3.

Williams, N., \& Efendic, A. (2019). Internal Displacement and External Migration in a Post-Conflict Economy: Perceptions of Institutions among Migrant Entrepreneurs. Journal of International Entrepreneurship, 17, 558-585.

https://doi.org/10.1007/s10843-019-00244-5 